Windle, J. and Briggs, D. (2015). "It's like working away for two weeks': The harms associated with young drug dealers commuting from a saturated London drug market'. Crime Prevention and Community Safety, 17(2): 105-119. Pre-publication copy

\title{
'It's like working away for two weeks': The harms associated with young drug dealers commuting from a saturated London drug market
}

\section{James Windle and Daniel Briggs ${ }^{1}$}

The final version of the paper as published in the print edition can be found at: http://www.palgravejournals.com/cpcs/journal/v17/n2/full/cpcs20152a.html

\begin{abstract}
This paper discusses some new developments in British illicit drug markets: the commuting of London-based gang members to sell drugs in other British towns, or in gang member's parlance: 'working the country lines'. This is concerning for several reasons, not least because children and young people may be running away from home and putting themselves at significant risk by dealing drugs; including involvement in the distribution of drugs from 'crack houses'. This paper hypothesises that the increased saturation of London drug markets is increasing the chances of drug dealers commuting from their homes which in turn raises particular harms, including conflict with established dealers in other cities as well as child welfare issues. The paper concludes with some policy and research recommendations.
\end{abstract}

\section{Key words}

\footnotetext{
${ }^{1}$ Dr James Windle, School of Business and Law, University of East London. Email address; J.Windle@uel.ac.uk
} 
Windle, J. and Briggs, D. (2015). "It's like working away for two weeks': The harms associated with young drug dealers commuting from a saturated London drug market'. Crime Prevention and Community Safety, 17(2): 105-119. Pre-publication copy

Gangs, drug markets, runaways, drug dealing, youth crime prevention, child welfare.

\section{Acknowledgements}

The author would like to thank Sinead Drew, Mark Wheeler and the anonymous referees for their thoughtful and constructive comments on early drafts.

\section{Introduction}

Very young people can become involved in gangs, ${ }^{2}$ and although not all will maintain affiliation once connected, participation with gangs and the lifestyle can significantly truncate other life opportunities. They may for example, drop out, or are excluded from school, increase their interactions with similar 'others' in the same arena and start to become more criminally involved in, for example, drug dealing (Bennett and Holloway, 2004; Briggs, 2010a, 2011; Curry et al. 2013; Klein et al., 2006; Pitts, 2008). In addition, belonging to, or being affiliated with, a gang increases the young persons risk of victimisation (Bullock and Tilley, 2002, 2008; Curry et al. 2013; Taylor et al. 2008). We acknowledge the small, but growing, body of work on British gangs (Alexander, 2008; Alleyene and Wood, 2010; Bradshaw, 2005; Ralphs et al. 2009), but would instead like to provide an initial exploration into an emerging trend in the context of gangs and drugs. One which impacts the welfare of young gang members and affiliates: young people commuting from London to sell drugs in other British towns.

\footnotetext{
${ }^{2}$ This article takes as a starting point the Eurogang definition of a gang as '...any durable, street-oriented youth group whose involvement in illegal activity is part of its group identity" (cited in Smithson et al. 2011: 54). For in-depth definitional debates please refer to Ian Joseph and Anthony Gunter (2011), Hannah Smithson and colleagues (2011) and, Wood and Alleyne
} (2010). 
Windle, J. and Briggs, D. (2015). "It's like working away for two weeks': The harms associated with young drug dealers commuting from a saturated London drug market'. Crime Prevention and Community Safety, 17(2): 105-119. Pre-publication copy

Our work is based upon a larger study which sought to investigate the activities and structure of gangs in one London borough. Over seven months in 2012, we interviewed seven practitioners and 12 self-identified gang members (hereafter 'gang members') in a London borough (see Methodology for details); anonymised here as Rose Borough. ${ }^{3}$ Interestingly, two of our gang member participants (Maxwell, Jermaine) and four of our practitioners (Adam, Ian, Jeremy, Paul), informed us that local drug markets had become increasingly saturated by a growing number of dealers and declining number of heroin and crack consumers. This resulted in the more entrepreneurial dealers leaving London to set up businesses in other parts of the UK. This has led to children and young people leaving home to distribute drugs in other cities.

When we refer to saturation, it is not only to suggest that increasing numbers of young people are entering the drug market as entrepreneurs, thereby 'saturating' the market though this maybe one trend taking place (Briggs, 2012; Hales and Hobbs, 2010; Ruggiero, 2010). Indeed, we have noted how increasingly young people in London (Briggs, 2010a), as well as across the country (Hall et al., 2008), engage in drug sales as a means of quickly earning large sums of money, as they look to display all the latest consumer goods which may not otherwise be available to them. However, there are other forces which also affect the drug market. Firstly, we need also to consider that we have seen a reduction in recorded levels of problematic drug use combined with an aging heroin population (NTA, 2013) and increased interdiction of supply (UNODC, 2013). There have also been various national, regional and local campaigns which have attempted to prevent the distribution of drugs which has led to the increased emphasis

\footnotetext{
${ }^{3}$ To reduce potential stigmatization of the research site and protect participants all names and locations have been anomyzed (Aldridge and Medina, 2008).
} 
Windle, J. and Briggs, D. (2015). "It's like working away for two weeks': The harms associated with young drug dealers commuting from a saturated London drug market'. Crime Prevention and Community Safety, 17(2): 105-119. Pre-publication copy

on a closed market structure operating by mobile phone (May and Duffy, 2007; Pitts, 2008; Briggs, 2012). As such, a growing number of motivated offenders, coupled with a reduction in demand for certain illicit drugs may have led to some local markets becoming increasingly saturated.

A number of participants to our study suggested that these market changes have led to children and young people leaving home to courier drugs out of London. They often distribute drugs from crack houses, sometimes for months at a time. These findings have been collaborated by a small number of media reports (Basingstoke Gazette, 2013; Birmingham Mail, 2013; Brown, 2014; Topping, 2014). This is an emergent gang and drug issue (see Measham et al. 2011) which to date has received scant attention from academia, the media or policy makers. This paper thus presents an initial foray into the topic using a single case study of our London borough. While our focus was upon drug dealers connected to a gang from Rose Borough, we were informed of similar developments in other East London boroughs. The next section presents our methodology.

\section{Methodology}

We conducted 12 open-ended interviews with young people who identified themselves, or had been identified as, former/current members of one of Rose Boroughs seven gangs and were attending Rose Boroughs Youth Offending Team (YOT). ${ }^{4}$ The research took place from June 2012 to January 2013. Access and interview rooms were

\footnotetext{
${ }^{4}$ While some of the participants initially claimed to not be gang members, as the interviews progressed they began to imply or openly state gang membership. In one case, a participant repeatedly asserted that he was not a gang member, yet presented from his pocket a bandana showing his gangs colours.
} 
Windle, J. and Briggs, D. (2015). "It's like working away for two weeks': The harms associated with young drug dealers commuting from a saturated London drug market'. Crime Prevention and Community Safety, 17(2): 105-119. Pre-publication copy

facilitated by Rose Borough YOT. Ethical clearance was provided by the University of East London Research Ethics Committee. Questions were specifically designed around eliciting information about the drug dealing activities and organisation of gangs in Rose Borough. Interviews lasted on average 45 minutes.

Participants were aged between 12 and 18 and mostly of minority ethnic background $(n=10)$, although two were white English $(n=2)$. All but one of the participants were male and either a member or former member of Red Gang. One female participant was, however, a member of another Rose Boroughs gang. All of these young people had been excluded from secondary school, had attended or were attending alternative educational sites where similar other 'problematic students' were attending. Some were using recreational drugs. Some had difficult family circumstances in that there had frequently been conflict in the family, either between them or between their parents. Most of these young people had a fairly unpredictable daily routine: staying up late, getting up late and showing little motivation to attend the YOT.

In general, their attendance at the YOT can be described as 'patchy': many haphazardly missed sessions claiming illness or because they felt threatened by having to travel through adversary's territory on the way to the YOT. They valued what the YOT tried to do by offering them group-work sessions or one-to-one cognitive therapy sessions but were realistic when they concluded that they could do little to alter the complexity of their daily lives: the difficult conditions in which they lived and the eminent pressures around them, such as the threat from gang adversaries. That fact that the majority of participants were from Red Gang is representative of the number of Red Gang members attending YOT. 
Windle, J. and Briggs, D. (2015). "It's like working away for two weeks': The harms associated with young drug dealers commuting from a saturated London drug market'. Crime Prevention and Community Safety, 17(2): 105-119. Pre-publication copy

We also interviewed six practitioners who worked in the Rose Borough YOT (four Youth Offending Officers and two senior managers working within the YOT) and one Metropolitan Police officer. ${ }^{5}$ These professionals had worked extensively with our sample and with numerous other young people from the area. They had a solid knowledge of the social pressures which these young people were exposed, the kind of situations that had led to their YOT attendance and the operations of local drug markets.

The recruitment of drug dealers is notoriously difficult. Therefore, as with similar studies (Lupton et al. 2002), our research site was partly chosen 'because of the quality of our pre-existing contacts' (May et al. 2005, p. 7) in the Rose Borough YOT. The research provided several limitations. Firstly, we were limited to gang members who were attending the Rose Borough YOT, and given the authoritative setting, it was difficult for some to feel totally comfortable about disclosing potentially sensitive information. We do not doubt the formalised setting of the YOT affected our data collection, however, we tried to overcome this by using established interviewing techniques, presenting ourselves as neutral to the YOT as well as impartial to their daily lives: as someone who would not judge them on their activities. Many with whom we had appointments failed to arrive and we lost many days to waiting around. Secondly, as the study excluded individuals from the older Rose Town-based gangs our knowledge of their operations was quite limited. The following section will introduce the coalition of four gangs we studied.

\section{Introducing Rose Borough and Rose Boys}

\footnotetext{
${ }^{5}$ This particular issue was also informally discussed with two police officers from Sussex police force, who collaborated many of our findings.
} 
Windle, J. and Briggs, D. (2015). "It's like working away for two weeks': The harms associated with young drug dealers commuting from a saturated London drug market'. Crime Prevention and Community Safety, 17(2): 105-119. Pre-publication copy

Rose Borough is one of London's most economically deprived areas. It has one the capitals highest proportion of children living in low income families (London Poverty Profile, 2013). Between July 2009 and June 2010, 13.2 percent of the boroughs population were unemployed; compared to the London average of nine percent, and UK average of 7.9 percent (Office of National Statistics, 2013).

While 12 gangs and peer groups were identified by Rose Borough YOT, we focused our attention on one coalition of four gangs; simply because members of one of the four gangs made up the majority of our participants. The four gangs are separated loosely by age: GBH (aged 21-25), Rose Boys (19-23), Red Gang (aged 14-18) and FDB (younger than 14). Each gang has roughly 20 core members and a significantly larger stable of individuals on the fringe of the four gangs which could be called upon for backup. ${ }^{6}$ This said, there was little agreement on numbers by gang members, which might be representative of the fluidity of the gang.

There was some disagreement over whether the coalition was one gang with different factions or four separate gangs. The majority of the gang members / former gang members we spoke to seemed to indicate that the four gangs were very separate entities with little routine interaction. One gang member discussed a 'leader' who exerted some authority over the four gangs. Although another gang member stated that the older gang members 'do not manage things' and, while they must be respected, their demands can be refused (for a more in-depth discussion see author, under consideration).

\footnotetext{
${ }^{6}$ While relationships are more complex than the core/fringe distinction implies (Papachristos, 2006), it does represent a useful starting point.
} 
Windle, J. and Briggs, D. (2015). "It's like working away for two weeks': The harms associated with young drug dealers commuting from a saturated London drug market'. Crime Prevention and Community Safety, 17(2): 105-119. Pre-publication copy

Red Gang, the gang for which we focused our attention, was vertically structured. That is, they did not appear to have central bureaucracies, budgets or leaders who make formal decisions for which all must obey (Curry et al., 2013). Rather they were loose networks of individuals, and smaller cliques, who cooperated through mutual selfinterest. They sold drugs as individual entrepreneurs rather than an established group, yet used the group to reduce the risk of robbery, intimidate potential rivals, and for the social benefits it presented (Author, under consideration; see also Aldridge and Medina, 2008; Bullock and Tilley, 2002, 2008; Decker, 2000; Smithson et al., 2011; Windle, 2013). That is, drug dealing did not appear to be centrally coordinated by a core gang leadership, or formal gang rules. The next section will describe the drug dealing activities of some gang members and how some commute from Rose Borough to sell drugs.

\section{Leaving London}

All four gangs sold cannabis, and to a much lesser extent heroin, cocaine and crack cocaine. Cannabis was predominantly sold within the borough and neighbouring boroughs. While demand for cannabis is high, the profits are reported to be minimal in relation to those of crack cocaine and heroin. One gang member estimated that crack cocaine sales were worth double that of cannabis, this is why several gang members reported concentrating their efforts on crack cocaine markets. The crack cocaine and heroin markets have, however, become saturated as the 'growing number of dealers is not accompanied by a growing number of user' (Ruggiero, 2010, p. 51; also Briggs, 
Windle, J. and Briggs, D. (2015). "It's like working away for two weeks': The harms associated with young drug dealers commuting from a saturated London drug market'. Crime Prevention and Community Safety, 17(2): 105-119. Pre-publication copy

2012; Hales and Hobbs, 2010). ${ }^{7}$ In response the more entrepreneurial gang members started looking elsewhere. In this context, entrepreneurial suggests a way of operating more effectively at avoiding the negative consequences of drug dealing, while at the same time, showing more gumption in profit-making, and maybe less concerned by issues of territory. In this way, our participants explained how they had learned from the mistakes made by their seniors in GBH and Rose Boys such as their carelessness with money, their propensity to get caught or engage in unprofitable violence.

One 17 year old Red Gang member explained how they adapted to this market change:

... most gang members will go to like in Scotland, Aberdeen coz you know there's more crack heads up there .... They'll go to Aberdeen, they'll go to Portsmouth, Cardiff (Maxwell).

Reading, Luton, High Wycombe and Berkshire were also identified by YOT workers as targets for Rose Borough gang members. One of senior manager at Red Borough YOT described how:

One of the young person that we currently have in custody at the moment he was missing for a period of about six months and every time he was picked up it was in Reading or Berkshire or places like that. In really, what the police describe, as high level crack house ...

\footnotetext{
${ }^{7}$ Bruce Jacobs (1999, p. 566) described how, towards the end of the 1990s, the St Louis street crack cocaine markets had become 'saturated and unprofitable' and the sellers 'who remain often compete over a relatively small, largely indigent cadre of street addicts'. The St Louis dealers adapted to the changing market by switching their attention from crack cocaine to heroin; which many perceived to be more profitable and less open to market fluctuations associated with crack consumpotion.
} 
Windle, J. and Briggs, D. (2015). "It's like working away for two weeks': The harms associated with young drug dealers commuting from a saturated London drug market'. Crime Prevention and Community Safety, 17(2): 105-119. Pre-publication copy

the young person would be placed in the home on their own and would literally just be there waiting on the door, he would give them the drugs them he would take the cash, erm very much doing the front line dealing (Adam).

While another officer at Red Borough YOT noted how young people are 'recruited' to traffic the drugs from London:

Yeh they recruit young lad to go and take their drugs for them, into other parts of the London area jump on the train for however long and because they were you know 12, 13 year old boys they're not going to get stopped by the police (Jeremy).

Informal discussions with police officers in Sussex have supported these findings. A similar issue has been raised by Gavin Hales and Dick Hobbs (2010) who reported gangs from another London borough commuting throughout the Home Counties, South Coast, Bristol, Birmingham and Ipswich. The Red Boroughs gang members have named commuting to sell drugs as working the 'country lines'.

Participants suggested that Red Gang were the more entrepreneurial of the coalition and the most active in drug markets outside of London. The coalition's two older gangs (GBH and Rose Boys) were reported to be less entrepreneurial and more interested in territorial disputes with neighbouring gangs. While they exploited non-London drug markets they reasoned that their impact was small.

Maxwell continued that Red Gang members would travel to other cities for about two weeks to sell crack cocaine: 
Windle, J. and Briggs, D. (2015). "It's like working away for two weeks': The harms associated with young drug dealers commuting from a saturated London drug market'. Crime Prevention and Community Safety, 17(2): 105-119. Pre-publication copy

It's like working away for two weeks ... [you] do your stuff, then once you've made your money come back, buy more do the same thing.

Maxwell did perceive some risk in distributing drugs outside of London. However, he weighed up the risk of arrest against establishing new markets which would increase demand for his business; whilst at the same time helping to avert violent confrontations with established London gangs. Conversely, Hale and Hobbs (2010, p. 27) found an increase in violent conflicts when gangs commute to areas where they have 'no prior knowledge or history of local dealers'. Such conflicts seem to have resulted from London dealers attempting to violently push competitors from the market while at the same time 'significantly undercutting them on price'.

Confrontations may, however, have been limited by gang members from Rose Borough entering into partnerships with established gangs and local dealers. It appears that in some towns members of a Somali gang collected Red Gang members and their affiliates from the train station, provided them with a mobile phone and took them directly to an existing crack house. One YOT worker suggested that these networks had been cultivated by gang members whilst in youth offender institutions. Topping (2014) suggests that gang members across London may have identified new markets after being relocated to social housing outside of London. Marcus Felson has suggested that people choose to offend, in this case sell drugs, in areas where they engage in routine activity. That is, most drug dealers sell drugs in the areas where they conduct their everyday lives: where they live, go to work and school, shop, exercise and socialise (Felson, 2008; also Brantingham and Brantingham, 2008). That is, few offenders are provided with opportunities to sell drugs in unfamiliar areas. As such, it is likely that 
Windle, J. and Briggs, D. (2015). "It's like working away for two weeks': The harms associated with young drug dealers commuting from a saturated London drug market'. Crime Prevention and Community Safety, 17(2): 105-119. Pre-publication copy

some prior connection would have been formed between our cohort and the towns to which they commute before they decided to sell drugs there.

A worrying aspect of this trend is that the practitioners we interviewed identified children and young people being paid 'a couple of hundred pound a week' (Paul) by members of the coalition to commute to sell crack cocaine and heroin. In one case a 12 year old child was found by authorities in a town in Buckinghamshire:

In what the police describe as high level crack house, not on a low level, like with serious class A. And the young person would be placed in the home on their own and would literally just be there waiting on the door, he would give them the drugs then he would take the cash, erm very much doing the front line dealing (Paul).

One Rose Borough YOT officer reported that many of these children and young people go missing for weeks at a time:

... we've been told what happens is their dropping out of school or they just don't turn up at school. So their getting reported missing and no one knows where they are .... they will literally go missing for six weeks ... One of the young person's that we currently have in custody at the moment he was missing for a period of about six months and every time he was picked up it was in Reading or Berkshire or places like that (Paul).

Maxwell, the 17 year old gang member who admitted commuting to sell drugs, did not employ children or other young people to sell drugs for him. This decision may depend 
Windle, J. and Briggs, D. (2015). "It's like working away for two weeks': The harms associated with young drug dealers commuting from a saturated London drug market'. Crime Prevention and Community Safety, 17(2): 105-119. Pre-publication copy

upon various factors including: possession of sufficient monetary, criminal and/or social capital to employ others, his skills at delegation, and, willingness to trust and/or share profits with others. This section has established that some teenagers are investing their money in cocaine and heroin procured in Rose Borough, which they leave home to sell in other British towns. Some teenagers, and possibly young adults, are also paying children to do this work for them; that is to traffic the drugs by train and/or distribute them from crack houses. The next section details some of the potential harms associated with the commutation from London.

\section{The impact of commuting to sell drugs}

These children and young people are being placed in potentially harmful situations which present both developmental and health risks. A 2011 survey of child runaways found that around one in nine had been hurt whilst away from home (Reece, 2011). While, in a 2003 study on adult and child missing persons, one in eight reported being hurt whilst living away from home; one in nine reported being sexually assaulted (Biehal et al., 2003; see also Wade, 2001). Additionally, going missing from home places strain on family relations and impacts educational performance (Evans et al., 2007). This situation is magnified by Rose Town children and young people's involvement in the drugs trade and residence in crack houses. Some of these locations will be sparsely furnished, unhygienic dwellings where they are at risk of being immersed in an environment of normalised crack/heroin consumption, hazardous sexual acts (often involving sex workers). They will also be in daily contact with adults who are consuming crack cocaine; a drug linked to violence and psychosis (Briggs, 2010b, 
Windle, J. and Briggs, D. (2015). "It's like working away for two weeks': The harms associated with young drug dealers commuting from a saturated London drug market'. Crime Prevention and Community Safety, 17(2): 105-119. Pre-publication copy

2012; Goldstein, 1985). ${ }^{8}$ Furthermore, these young people are living in environments with elevated opportunities to offend and engage in risky behaviour (i.e. smoke cigarettes, drink alcohol); with an absence of intimate handlers (parents, teachers, YOT workers) who might be able to limit such behaviour (Felson, 2008).

This section has shown how young people from Rose Borough, and neighbouring boroughs, are exposed to potentially harmful situations by leaving home to sell crack cocaine and heroin. These risks may blur the line between perpetrator and victim. Furthermore, that these children and young people operate in more underground and illicit circumstances increases the likelihood of them being 'hidden' from state support. The next section discusses some policy implications of this research.

\section{Policy and research implications}

Unfortunately, the climate for effective intervention may impede immediate changes to this emerging phenomenon. Working with youths who have gone missing, and committed serious offences whilst away, requires resources and time that many agencies are lacking (Evans et al., 2007; Hourigan, 2011). Recent cases of child abuse (such as Baby P and Victoria Climbié) expose the shortfalls of not only the child care system but mechanisms of joint working which seem to be promised as areas for improvement by national, regional and local governments. Perhaps related to this, which also has direct

\footnotetext{
${ }^{8}$ While the negative effects of crack cocaine use are well documented it is worth bearing in mind that there are many distorted images of what it means to be a consumer of crack (see Reinarman and Levine, 1997). We are not trying to demonise crack cocaine consumers with stereotypical images but rather identify some of the contextual factors surrounding some crack cocaine markets.
} 
Windle, J. and Briggs, D. (2015). "It's like working away for two weeks': The harms associated with young drug dealers commuting from a saturated London drug market'. Crime Prevention and Community Safety, 17(2): 105-119. Pre-publication copy

implications for a meaningful response, are public and health service funding cuts and the streamlining of social services in general (Topping, 2014).

Perhaps the best place to start is to consider some research projects to establish the gravity of the phenomenon. One focus could be how children and young people are recruited to undertake these duties and how new markets outside urban areas are identified: especially how connections are made between drug dealers/gang members in London and other towns. It is only with credible research that preventive and harm reductionist policies and interventions can be developed (Brown, 2006; Bullock et al., 2002; Laycock and Tilley, 1995). Crime script analysis (Cornish, 1994) may be particular helpful in investigating how drugs are procured, trafficked and sold.

There does already exist some policy around the support for exploited children and young people who may leave home (Reese, 2011). As the Statutory Guidelines on Children who Run Away and Go Missing from Care or Home state:

Running away can be symptomatic of wider problems in a child or young person's life, but whatever the reason, one thing is very clear: children who decide to run away are unhappy, vulnerable and in danger (DCSF, 2009. p. 3).

Our participants demonstrate some of these attributes in that some had experienced emotional and/or physical abuse, or neglect. Similarly, as previous research into youth gangs (see Howell and Egley, 2005) and some of our sample would suggest, their parents or caregivers may be dealing with mental health issues, alcohol or drug dependency (DCSF, 2009; Evans et al., 2007; Malloch and Burgess, 2011), or an inability to cope with difficult financial, environmental or emotional circumstances. 
Windle, J. and Briggs, D. (2015). "It's like working away for two weeks': The harms associated with young drug dealers commuting from a saturated London drug market'. Crime Prevention and Community Safety, 17(2): 105-119. Pre-publication copy

We suggest that there are some basic areas where social support agencies (schools, YOTs, third sector organisations, etc) could improve their response. The predominant issue is to ensure they have mechanisms in place to record and report children and young people who may be missing. Research already shows that the role of the police is rather limited in this respect as $70 \%$ of children and/or young people who leave home are not reported missing to the police. This is because parents or caregivers may want to avoid involvement with the police or social services, or may have known where the child has gone (Reece, 2011). This makes the response problematic.

There is the potential for further complications since the police may not consider these children and young people 'real' runaways but rather 'troubled youths'. This perception may be augmented if the child/teenager is distrustful of the police and puts on a tough front (Malloch and Burgess, 2011). Instead, agencies and institutions such as social services, YOTs and schools should attempt to identify risk factors and provide support to runaways and their families/carers. Many of these recommendations are already present in the Statutory Guidelines on Children who Run Away and go Missing from Care or Home (DCSF, 2009).

While multiagency cooperation between social services, foster care agencies, schools, YOT teams, police and third sector agencies is often a central feature of successful crime prevention policies, several of the practitioners we interviewed identified the lack of cooperation as a significant barrier (see also Evans et al., 2007). Inter-agency cooperation is notoriously difficult in crime preventive and tends to be limited by poor communication, suspicion, competition, ignorance and different institutional cultures 
Windle, J. and Briggs, D. (2015). "It's like working away for two weeks': The harms associated with young drug dealers commuting from a saturated London drug market'. Crime Prevention and Community Safety, 17(2): 105-119. Pre-publication copy

(Laycock and Tilley, 1995; Scott, 2006; Liddle and Gelsthorpe, 1994; for further discussion on implementing inter-agency polices see Klima et al., 2012).

Sometimes there is confusion about roles and responsibilities. As a respondent to a study conducted by Margaret Malloch and Cheryl Burgess (2011, p. 67) notes: 'Police think it is a social work responsibility; social work think it is a police responsibility' Furthermore, much data collected on reported missing persons by the police is often 'inaccurate and incomplete' (Malloch and Burgess, 2011, p. 66): different forces collect different data, and often fail to share with other, non-criminal justice, agencies such as Children's Services (Evans et al., 2007). These issues may be exacerbated by a lack of awareness about the issue and here is where researchers enter the equation.

\section{Conclusion}

This paper has presented an initial investigation into an emergent drug and gang issue which has yet to receive sufficient academic, policy or media attention. Some of our participants suggested that local drug markets had become increasingly saturated with a declining number of crack and heroin users and an increasing number of drug dealers. In response, more entrepreneurial dealers began migrating to less overcrowded and competitive towns outside of London. One self-identified gang member discussed 'working away for two weeks' in order to increase demand for his business whilst avoiding confrontation with other London gangs. The practitioners we interviewed suggested that some dealers are exploiting children and young people to courier and distribute drugs.

Previous research on child and young person runaways, and on the operation of some crack cocaine markets, suggests that many of these children and young people are at 
Windle, J. and Briggs, D. (2015). "It's like working away for two weeks': The harms associated with young drug dealers commuting from a saturated London drug market'. Crime Prevention and Community Safety, 17(2): 105-119. Pre-publication copy

heightened risk of exposure to potentially harmful situations, including physical and sexual assault. The absence of intimate handlers may expose them to greater opportunities to offend and consume illicit drugs, further inflating their chances of interaction with the youth justice system. In addition, absence from school reduces their opportunities for future economic and social success. While it appears that our cohort entered into cooperative alliances with local dealers, those who attempt to break new markets may risk the retaliation of rivals for market share: Presenting an additional dimension of risk for children and young people involved in drug distribution.

The evidence presented here suggests that further investigation is needed into children and young people commuting from London to sell drugs in other towns. We need greater understanding of:

- the mechanisms by which children and young people are recruited to courier and sell illicit drugs;

- how new markets are identified and penetrated;

- the impact of leaving home and being immersed in illicit drug markets on children and young people;

- how agencies are currently dealing with an emerging issue.

This evidence base will support the development of interventions. It is suggested that effective interagency cooperation will be required to prevent drug dealing and limit the harms caused to these children and young people. 
Windle, J. and Briggs, D. (2015). "It's like working away for two weeks': The harms associated with young drug dealers commuting from a saturated London drug market'. Crime Prevention and Community Safety, 17(2): 105-119. Pre-publication copy

This is not, however, to say that the trend will continue. In North American, during 2013 / early-2014 a trend of increasing heroin consumption emerged; primarily brought about by low prices and increased availability (CBC, 2014; Chen and Wilber, 2014; DiSalvo, 2014). If this trend were to cross over to the UK then it is possible that Red Borough's local dealers would cease commuting because, as those who commute long distances for work know, people only 'work away' from home when they have to.

\section{References}

Alexander, C. (2008). (Re)Thinking 'Gangs'. London: Runnymead Trust.

Aldridge, J. and Medina, J. (2008). Youth Gangs in an English City: Social Exclusion, Drugs and Violence: Full Research Report ESRC End of Award Report, RES-000-230615. Swindon: ESRC

Alleyene, E. and Wood, J.L. (2010). Gang Involvement: Psychological and Behavioural Characteristics of Gangs Members, Peripheral Youth and Non-Gang Youth. Aggressive Behaviour. Vol. 36, No. 6, pp. 423-436.

Basingstoke Gazette (2013). Teenage Drugs Mule Stashed Cocaine and Heroin, Basingstoke Gazette, 30 ${ }^{\text {th }}$ November 2013.

Bennett, T. and Holloway, K. (2004). Gang Membership, Drugs and Crime in the UK. British Journal of Criminology. Vol. 44, No. 3, pp. 305-323.

Biehal, N., Mitchell, F. and Wade, J. (2003). Lost from View: Missing Persons in the UK. Bristol: The Policy Press. 
Windle, J. and Briggs, D. (2015). "It's like working away for two weeks': The harms associated with young drug dealers commuting from a saturated London drug market'. Crime Prevention and Community Safety, 17(2): 105-119. Pre-publication copy

Birmingham Mail (2013). Gang Forced Boys to Courier Crack Hidden in Ritz Cracker Boxes. Birmingham Mail, 18th August 2013.

Bradshaw, P. (2005). Terrors and Young Teams: Youth Gangs and Delinquency in Edinburgh. In Decker, S.H., and Weerman, F.M. (eds.) European Street Gangs and Troublesome Youth Groups. Oxford: Rowman and Littlefield.

Brantingham, P. and Brantingham, P. (2008). Crime Pattern Theory. In Wortley, R. and Mazerolle, L. (eds.) Environmental Criminology and Crime Analysis. Devon, UK: Willan.

Briggs, D. (2010a). The World is Out to Get Me, Bruv: Life After School Exclusion. Safer Communities. Vol. 9, No. 2, pp. 9-19.

Briggs, D. (2010b). Crack Houses in the UK: Some Observations on their Operations. Drugs and Alcohol Today. Vol. 10, No. 4, pp. 33-42.

Briggs, D. (2011). New Avenues to School Exclusion and Social Exclusion for Urban Young People in the UK. In Bass, L. and Kinney, D. (eds.). Sociological Studies of Children and Youth. Michigan: Emerald.

Briggs, D. (2012). Crack Cocaine Users: High Society and Low Life in South London. London: Routledge.

Brown, R. (2006). The Role of Project Management in Implementing Community Safety Initiatives. In Knutsson, J. and Clarke, R.V. (eds.) Putting Theory to Work: Implementing Situational Crime Prevention and Problem-Oriented Policing. Devon: Willan. 
Windle, J. and Briggs, D. (2015). "It's like working away for two weeks': The harms associated with young drug dealers commuting from a saturated London drug market'. Crime Prevention and Community Safety, 17(2): 105-119. Pre-publication copy

Brown, R. (2014). How London Dealers are 'Commuting' to Cambridge in Drugs 'Gold Rush'. Cambridge News, $8^{\text {th }}$ Febuary 2014.

Bullock, K. and Tilley, N. (2002). Shootings, Gangs and Violent Incidents in Manchester: Developing a Crime Reduction Strategy. Crime Reduction Research Series Paper 13. London: Home Office.

Bullock, K. and Tilley, N. (2008). Understanding and Tackling Gang Violence. Crime Prevention and Community Safety. Vol. 10, No. 1, pp. 36-47.

Bullock, K., Farrell, G. and Tilley, N. (2002). Funding and Implementing Crime Reduction Projects. London: Home Office.

CBC News. (2014). Heroin Resurgence as 'Problem Drug' in Canada. CBC News, 6th February 2014, consulted online 23rd February 2014, http://www.cbc.ca/news/health/heroin-s-resurgence-as-problem-drug-in-canada1.2525103

Chen, C. and Wilber, D.C. (2014) Heroin Resurgence Seen Sparkeds by Cheap Cost, Easy Availability. Chicago Tribune, 3rd February 2014.

Cornish, D. (1994). The Procedural Analysis of Offending and its Relevance for Situational Prevention. In Clarke, R. (ed.). Crime Prevention Studies, New York: Criminal Justice Press.

Curry, G.D., Decker, S.H. and Pyrooz, D.C. (2013). Confronting Gangs: Crime and Community. Oxford: Oxford University Press. 
Windle, J. and Briggs, D. (2015). "It's like working away for two weeks': The harms associated with young drug dealers commuting from a saturated London drug market'. Crime Prevention and Community Safety, 17(2): 105-119. Pre-publication copy

Decker, S.H. (2000). Legitimating Drug Sales: A Note on the Impact of Gang Membership and Drug Sales on the Use of Illicit Drugs. Justice Quarterly. Vol. 17, No. 2, pp. 394-410.

DCSF (Department of Children, Schools and Family). (2009). Statutory Guidance on Children who Run Away and Go Missing From Home or Care. London: DCSF.

DiSalvo, D. (2014) Why is Heroin Abuse Rising While Others Dug Abuse is Falling? Forbes, 1st February 2014, consulted online, 23rd February 2014, http://www.forbes.com/sites/daviddisalvo/2014/01/14/why-is-heroin-abuse-risingwhile-other-drug-abuse-is-falling/

Evans, K., Houghton-Brown, M. and Rees, G. (2007). Stepping Up: The Future of Runaways Services. The Children's Society.

Felson, M. (2008). Routine Activity Approach. In Wortley, R. and Mazerolle, L. (eds.) Environmental Criminology and Crime Analysis. Devon, UK: Willan.

Goldstein, P. (1985). The Drug/Violence Nexus: A Tripartite Conceptual Framework. Journal of Drug Issues, Vol. 14, No. 3, pp. 493-506.

Hales, G. and Hobbs, D. (2010). Drug Markets in the Community: A London Borough Case Study. Trends in Organised Crime. Vol. 13, No. 1, pp. 13-30.

Hall, S., Winlow, S. and Ancrum, C. (2008). Criminal Identities and Consumer Culture: Crime, Exclusion and the New Culture of Narcissism, Cullumpton: Willan. 
Windle, J. and Briggs, D. (2015). "It's like working away for two weeks': The harms associated with young drug dealers commuting from a saturated London drug market'. Crime Prevention and Community Safety, 17(2): 105-119. Pre-publication copy

Hourigan, N. (2013). 'Lessons from Limerick: Policing, Child Protection, Regeneration'. In Hourigan, N. (Ed.). Understanding Limerick: Social Exclusion and Change. Cork: Cork University Press. and Howell, J.C. and Egley, A. (2005). Moving Risk Factors into Developmental Theories of Gang Membership. Youth Violence and Juvenile Justice, Vol. 3, No. 4, pp. 334-354. Jacobs, B.A. (1999). Crack to Heroin? Drug Markets and Transition. British Journal of Criminology, Vol. 39, No. 4, pp. 555-574.

Joseph, I. and Gunter, A. (2011). What's a Gang and what's Race got to do with it? London: Runnymede Trust.

Klein, M., Weerman, F.M. and Thornberry, T.P. (2006). Street Gang Violence in Europe. European Journal of Criminology. Vol. 3, No. 4, pp. 413-437.

Klima, N., Vanhauwaert, R. and Wijckmans, B. (2012). Local Cooperation in Youth Crime Prevention. EUCPN Toolbox Series, Brussels: European Crime Prevention Network.

Laycock, G. and Tilley, N. (1995). Implementing Crime Prevention. In Tonry, M. and Farrington, D. (eds.) Building a Safer Society, Crime and Justice: A Review of Research. Chicago: University of Chicago Press.

Liddle, A.M. and Gelsthorpe, L. (1994). Crime Prevention and Inter-Agency Cooperation. London: Home Office.

London Poverty Profile. (2013), Poverty Indicators. Available online: http://www.londonspovertyprofile.org.uk/indicators/ 
Windle, J. and Briggs, D. (2015). "It's like working away for two weeks': The harms associated with young drug dealers commuting from a saturated London drug market'. Crime Prevention and Community Safety, 17(2): 105-119. Pre-publication copy

Lupton, R. Wilson, A., May, T., Warburton, H., \& Turnbull, P. J. (2002). A Rock and a Hard Place: Drug Markets in Deprived Neighbourhoods. London: Home Office.

Malloch, M.S. and Burgess, C. (2011). Responding to Young Runaways: Problems of Risk and Responsibility. Youth Justice. Vol. 11, No. 1, pp. 61-76.

May, T., and Duffy, M. (2007). Drug Dealing in Local Communities, London: Nacro.

May, T., Duffy, M., Few, B. and Hough, M. (2005). Understanding Drug Selling in Communities: Insider or Outsider Trading? London: Joseph Rowntree Foundation.

Measham, F., Moore, K. and Ostergaard, J. (2011). Mephedrone, "Bubble" and Unidentified White Powders: The Contested Identities of Synthetic "Legal Highs". Drugs and Alcohol Today, Vol. 11, N. 3, pp. 137-146.

NTA (National Treatment Agency) (2013) Falling Drug Use: The Impact of Treatment, London: NTA.

Office of National Statistics. (2013), Neighbourhood Statistics. Available online: http://www.ons.gov.uk/ons/index.html

Papachristos, A.V. (2006). Social Network Analysis and Gang Research: Theory and Method. In Short, J.E. and Hughes, L.A. (eds.) Studying Youth Gangs. Oxford: AltaMira Press.

Pitts, J. (2008). Reluctant Gangsters: The Changing Face of Youth Crime. Devon: Willan 
Windle, J. and Briggs, D. (2015). "It's like working away for two weeks': The harms associated with young drug dealers commuting from a saturated London drug market'. Crime Prevention and Community Safety, 17(2): 105-119. Pre-publication copy

Ralphs, R., Medina, J. and Aldridge, J. (2009). Who Needs Enemies with Friends Like These? The Importance of Place for Young People Living in Known Gang Areas. Journal of Youth Studies. Vol. 12, No. 5, pp. 483-500.

Rees, G. (2011), Still Running 3: Early Findings from our Third National Survbey of Young Runaways, 2011. London: The Children Society.

Reinarman, C., and Levine, H. (1997) Crack in America: Demon Drugs and Social Justice, Los Angeles: University of California Press.

Ruggiero, V. (2010). Unintended Consequences: Changes in Organised Drug Supply in the UK. Trends in Organized Crime. Vol. 13, Vol. 1, pp. 46-59.

Scott, M. (2006). Implementing Crime Prevention: Lessons Learned from ProblemOriented Policing Projects. In Knutsson, J. and Clarke, R. (eds), Putting Theory to Work: Implementing Situational Crime Prevention and Problem-Oriented Policing. Devon: Willan.

Smithson, H., Monchuk, L. and Armitage, R. (2011). Gang Member: Who Says? Definitional and Structural Issues. In Esbensen, F.A. and Maxson, C.L. (eds.) Youth Gangs an International Perspective: Tales from the Eurogang Program of Research. London: Springer.

Taylor, T.T., Freng, A., Esbensen, F. and Peterson, D. (2008). Victimization: The Importance of Lifestyles and Routine Activities. The Journal of Interpersonal Violence. Vol. 23, No. 10, pp. 1441-1464.

Topping, A. (2014). London Gangs are Using Children as Drug Mules as They Seek to Expand Drug Markets. The Guardian, $5^{\text {th }}$ January 2014. 
Windle, J. and Briggs, D. (2015). "It's like working away for two weeks': The harms associated with young drug dealers commuting from a saturated London drug market'. Crime Prevention and Community Safety, 17(2): 105-119. Pre-publication copy

UNODC (United Nations Office of Drugs and Crime) (2013). World Drug Report. Vienna: UNODC.

Wade J (2001). Missing Out: Young Runaways in Scotland. Stirling: Aberlour Child Care Trust.

Windle, J. (2013). Tuckers Firm: A Case Study of British Organised Crime. Trends in Organised Crime, Vol. 16, No. 4, pp. 382-396.

Wood, J. and Alleyne, E. (2010). Street Gang Theory and Research: Where are we now and where do we go from here? Aggression and Violent Behaviour, Vol. 15, No. 2, pp. 100-111.

Author 